\title{
Pengaruh Return On Equity dan Leverage Pada Saham Bonus di Perusaaan yang Terdaftar di Bursa Efek Indonesia
}

\author{
Rai Sukmawati Danaํ, Komang Ayu Krisnadewi² \\ 1,2 Fakultas Ekonomi dan Bisnis Universitas Udayana
}

Key words:

RO

Leverage

Bonus shares

\begin{abstract}
A B S T R A C T
This study aimed to determine the effect of return on equity (ROE) and leverage of the bonus shares in companies listed on the Stock Exchange in 20002015. The total samples that used ware 33 observations based on saturated samples method. The analysis technique used multiple linear regression analysis. The results showed ROE does not had an effect on bonus shares that means the company's decision to publish bonus shares does not depend on the size of ROE, leverage had a positive effect on bonus shares that shows if the company's risk increased, so the possibility of the company to publish bonus shares will higher than cash dividends in the future.
\end{abstract}

\section{A B S T R A K}

Penelitian ini bertujuan untuk mengetahui pengaruh return on equity (ROE) dan leverage pada saham bonus di perusahaan yang terdaftar di BEI tahun 20002015. Jumlah sampel yang digunakan sebanyak 33 amatan berdasarkan metode sampel jenuh. Teknik analisis yang digunakan adalah analisis regresi linear berganda. Hasil penelitian menunjukkan bahwa ROE tidak berpengaruh terhadap saham bonus yang menunjukkan keputusan perusahaan untuk mengambil kebijakan saham bonus tidak bergantung pada besar kecilnya ROE, leverage berpengaruh positif terhadap saham bonus yang menunjukkan bahwa semakin tinggi risiko yang dimiliki suatu perusahaan, maka semakin besar kemungkinan perusahaan menerbitkan saham bonus dibandingkan deviden tunai di masa yang akan datang.

\section{PENDAHULUAN}

Pasar modal pada dasarnya merupakan pasar yang mewadahi terjadinya suatu transaksi sekuritas jangka panjang seperti saham dan obligasi (Jones, 2006). Melalui keberadaan pasar modal tercipta suatu hubungan antara pihak yang memiliki dana (investor) dengan pihak yang membutuhkan dana (emiten). Emiten diperintahkan investor untuk melakukan tugas demi kepentingan investor, termasuk memberikan informasi yang berkaitan dengan investasi mereka. Salah satu kegiatan emiten yang memiliki peluang untuk menghasilkan informasi adalah aksi korporasi (corporate action). Corporate action atau disebut juga dengan aksi emiten merupakan suatu kegiatan atau aktivitas yang dilakukan oleh emiten yang dipandang mempunyai kemungkinan mempengaruhi harga saham di bursa efek (Gitman, 2006:193). Adanya peningkatan pada modal disetor yang kedepannya akan berdampak pada likuiditas perdagangan saham merupakan tujuan utama dari dilaksanakannya suatu aksi korporasi oleh perusahaan karena dipandang menguntungkan bagi kelangsungan hidup perusahaan itu sendiri.

Surat tanda hutang atau yang sering disebut dengan obligasi dan surat tanda kepemilikan saham merupakan sekuritas yang dikeluarkan oleh suatu perusahaan dengan adanya pasar modal, maka dari itu peningkatan nilai debt to equity ratio dapat dihindari oleh perusahaan. Namun demikian melalui keberadaan pasar modal, perusahaan tidak akan selalu mengeluarkan saham. Berdasarkan teori keuangan, setiap sumber dana pasti memiliki biaya dana (cost of capital) baik yang berasal dari pinjaman maupun dari modal perusahaan itu sendiri. Perbedaannya terletak pada sifatnya, sumber dana yang berasal dari pinjaman cenderung memiliki sifat eksplisit sebab

\footnotetext{
*Corresponding author, email address: 1 raisukmawatidana@gmail.com, 2 komangayukrisnadewi@unud.ac.id
} 
dikeluarkan langsung oleh perusahaan dalam bentuk pembayaran bunga, sedangkan untuk sumber dana yang berasal dari modal sendiri cenderung memiliki sifat implisit.

Corporate action erat kaitannya dengan beberapa kejadian di pasar modal, antara lain share split, right issue, pembagian dividen, dan saham bonus. Penurunan likuiditas saham suatu perusahaan akan terjadi apabila adanya penilaian kinerja perusahaan yang kurang maksimal oleh pemegang saham. Hal tersebut menjadi suatu motivasi bagi manajemen perusahaan untuk mengupayakan suatu kebijakan yang kedepannya dapat menyebabkan peningkatan pada likuiditas perusahaan. Salah satu kebijakan yang dipandang mampu mengatasi hal tersebut adalah memberikan saham bonus kepada pemegang saham.

Saham bonus merupakan salah satu bagian dari corporate action yang dipandang dapat mempengaruhi harga dan banyaknya saham yang beredar di pasar modal (Sianipar, 2006). Dalam peraturan BAPEPAM-LK nomor Kep-35/PM/2003 dijelaskan bahwa saham bonus (bonus share) adalah saham baru yang dibagikan tanpa imbalan kepada pemegang saham berdasarkan proporsi kepemilikannya. Saham bonus hanya dapat dimiliki oleh pemegang saham yang masih memiliki hak memegang saham perusahaan hingga akhir masa cum-date (cummulative date).

Keuntungan dari dilakukannya kebijakan saham bonus bagi emiten adalah dapat menjadi suatu upaya dalam peningkatan kinerja perusahaan tanpa merugikan pemegang saham (Adiati, 2006). Saham bonus dari sisi investor, meskipun secara riil tidak memberikan peningkatan dalam nilai investasinya, investor dalam jangka panjang dapat memperoleh potensi keuntungan dari kenaikan harga saham akibat lebih likuidnya perdagangan saham dengan harga yang relatif murah. Kebijakan saham bonus erat kaitannya dengan teori keagenan karena ketika terjadinya suatu hubungan agency, akan cenderung menyebabkan timbulnya biaya agency. Biaya agency adalah biaya yang dikeluarkan emiten sebagai upaya untuk mempertahankan keefektifan hubungan agency (Balachandran et al., 2001). Salah satu dari upaya tersebut adalah menawarkan bonus kepada investor dalam bentuk saham dan bonus kepada manajer dalam bentuk insentif untuk meningkatkan kinerja perusahaan.

Hubungan antara agent dan principal dijelaskan pada teori keagenen (Jensen dan Meckling, 1976). Pendelegasian otorisasi pengambilan keputusan dari principal kepada agent merupakan tugas yang diperintahkan oleh principal kepada agent dalam tujuan untuk memenuhi kepentingan principal. Dalam konteks pasar modal, yang berperan sebagai principal adalah pemegang saham sedangkan yang berperan sebagai agent adalah manajemen perusahaan. Menurut Anthony dan Govindarajan (2006:139) teori agensi menggambarkan bahwa semua pihak melakukan sesuatu berdasarkan kepentingannya sendiri sehingga menimbulkan konflik kepentingan antara principal dan agent. Teori keagenan menjelaskan bahwa terdapat konflik antara agent dan principal dimana konflik tersebut dinamakan konflik keagenan (Hebble, 2005). Pemegang saham dalam hal ini ingin memperoleh kesejahteraan dari modal yang ditanamkan dengan mendapatkan deviden yang tinggi, namun pada saat yang bersamaan kondisi perusahaan tidak memungkinkan untuk memberikan deviden yang tinggi karena likuiditasnya menurun. Perusahaan di lain pihak ingin menyejahterakan dirinya sendiri untuk meningkatkan likuiditas perusahaan. Disinilah terjadi perbedaan kepentingan yang mengakibatkan konflik keagenan antara pemegang saham dan manajemen perusahaan.

Menurut Crutchley et al. (1999) kebijakan saham bonus dianggap strategi yang baik sebagai solusi dalam mengatasi konflik keagenan. Penelitian sebelumnya menunjukkan hal-hal yang menyebabkan dikeluarkannya kebijakan saham bonus adalah rentabilitas dan leverage. Wibawa (2015) menyatakan bahwa terdapat pengaruh negatif antara rentabilitas (ROE) dengan saham bonus. Penelitian Rozeff (1982) menyatakan bahwa perusahaan akan mengambil kebijakan saham bonus apabila memiliki nilai leverage tinggi karena akan berdampak pada penurunan pembayaran deviden kepada pemegang saham dengan maksud untuk meminimalkan ketergantungan pinjaman dari luar.

\section{RERANGKA TEORI DAN PERUMUSAN HIPOTESIS}

Adaoglu et al. (2003) menyatakan bahwa pembagian saham bonus dapat dilakukan apabila pada suatu perusahaan masih memiliki jumlah saham yang cukup serta masih memiliki saldo agio saham. Agio tersebut diperoleh dari hasil pengurangan harga nominal dan harga penawaran saham pada saat right issue maupun saat IPO. Pembagian saham bonus seringkali dilakukan oleh perusahaan karena secara teoritis hanya terjadi perpindahan pencatatan pada neraca namun tidak mempunyai dampak pada kas perusahaan akibat 
dibagikannya saham bonus. Pembagian saham bonus tidak merubah nilai ekuitas pemegang saham sehingga kapitalisasi pasar juga tidak berubah.

Keadaan dimana penilaian investor terhadap kinerja perusahaan tidak maksimal mengharuskan perusahaan mengambil kebijakan saham bonus (Shirur, 2008). Perusahaan mengetahui penilaian investor terhadap kinerja perusahaan kurang baik melalui volume penjualan saham perusahaan yang terus meningkat, sehingga akan memiliki dampak yang buruk bagi aktivitas perusahaan. Kebijakan saham bonus umumya dilakukan oleh perusahaan apabila sedang dalam kondisi tertentu, salah satunya terjadi peningkatan harga saham pada pasar namun pada kondisi yang sama masih terdapat agio saham dengan jumlah yang besar pada perusahaan. Tingginya harga saham mengakibatkan likuiditas menjadi rendah karena investor tidak dapat menjangkau. Menurut Barnes dan Shuguang Ma (2002), pembagian saham bonus diharapkan membuat harga saham menurun karena mengalami penyesuaian sehingga likuiditas di pasar naik kembali. Penurunan harga saham akibat penerbitan saham bonus ini juga dinyatakan oleh Sunariyah (2010:92). Transaksi jual beli saham akan lebih mudah sehingga menguntungkan investor dalam berinvestasi disebabkan karena adanya penurunan pada harga saham perusahaan.

Menurut Kennedy (2003), rasio yang menggambarkan upaya perusahaan dalam pengelolaan modal sendiri yang secara langsung dapat mengetahui tingkat keuntungan yang akan diperoleh dari investasi pemegang saham disebut dengan return on equity (ROE) atau tingkat pengembalian ekuitas pemilik. Hubungan antara earning after tax (EAT) dengan modal sendiri digunakan dalam perhitungan return on equity (ROE). Saham biasa, agio saham, laba ditahan, saham preferen dan cadangan-cadangan lain merupakan modal sendiri yang dimaksudkan. Berdasarkan hubungan tersebut maka dapat disimpulkan bahwa return on equity (ROE) merupakan rentabilitas ekonomi. Barclay dan Holderness (1990) menyatakan bahwa rentabilitas ekonomi adalah rasio tujuan akhir yang menggambarkan pengembalian nilai buku kepada pemilik perusahaan.

Nilai ROE suatu perusahaan menggambarkan kinerja manajemen dalam upaya pemanfaatan investasi pemegang saham. ROE diukur dalam satuan persen. Terdapat hubungan positif antara return on equity (ROE) dengan harga saham, sehingga apabila terjadi suatu peningkatan pada nilai ROE perusahaan maka akan diikuti dengan peningkatan harga pasar. Peningkatan nilai return on equity (ROE) perusahaan menggambarkan bahwa akan terjadi peningkatan atas return yang akan diperoleh investor, dengan demikian investor akan tertarik untuk berinvestasi pada saham perusahaan tersebut yang otomatis akan menyebabkan peningkatan harga saham dipasar. Menurut Lestari dan Sugiharto (2007) nilai return on equity dikatakan memenuhi target apabila $>12 \%$. Menghasilkan keuntungan yang bermanfaat bagi pemegang saham merupakan tujuan utama dari beroperasinya suatu perusahaan. Tujuan tersebut dapat dikatakan tercapai apabila nilai ROE dapat dicapai perusahaan.

Rentabilitas modal sendiri (ROE) menurut Riyanto (2010:86) merupakan rasio antara jumlah keuntungan yang tersedia bagi pemilik modal sendiri di satu pihak dengan jumlah modal sendiri yang menghasilkan keuntungan di lain pihak. Lestari dan Sugiharto (2007) menyatakan bahwa peningkatan nilai ROE menggambarkan terjadi peningkatan pula pada kinerja perusahaan dalam hal pengelolaan modal sehingga akan mengakibatkan peningkatan deviden yang akan diperoleh pemegang saham. ROE yang positif menunjukkan bahwa aktivitas operasi perusahaan mampu menghasilkan laba dari total ekuitas yang digunakan sehingga peluang untuk membagikan saham bonus rendah.

ROE dapat menyebabkan apresiasi dan depresiasi harga saham (Holderness dan Sheehan, 1988). Keuntungan yang dihasilkan dari pengelolaan penggunaan modal memiliki dampak bagi pemegang saham perusahaan. ROE yang baik akan menjadi perhatian bagi pemegang saham karena mengacu pada pemberian deviden. Penurunan likuiditas perusahaan disebabkan oleh pembagian deviden. Maka dari itu, perusahaan berasumsi bahwa pengambilan kebijakan saham bonus adalah alternatif yang tepat karena dapat meningkatkan jumlah modal disetor, baik yang berasal dari investor maupun kreditor dalam bentuk hutang.

Modal merupakan hal pokok yang dibutuhkan perusahaan dalam melakukan kegiatan operasional setiap harinya baik yang bersumber dari hutang maupun yang bersumber dari modal sendiri. Kebijakan leverage menerapkan pengunaan sumber dana secara eksternal baik berupa jangka panjang maupun jangka pendek untuk pembiayaan aktivitas operasional perusahaan. Leverage memiliki tujuan yang sama dalam hal keuangan yaitu untuk memenuhi tujuan dalam pencapaian peningkatan 
laba yang diharapkan. Kemampuan perusahaan dalam memanfaatkan aktiva atau dana yang memiliki beban tetap guna meningkatkan return bagi pemegang saham digambarkan oleh leverage. Sjahrial (2007:138) menyatakan bahwa leverage merupakan pemanfaatan aktiva yang memiliki biaya tetap (beban tetap) berarti sumber dana yang berasal dari hutang karena memiliki bunga sebagai beban tetap dengan maksud agar dapat meningkatkan keuntungan potensial pemegang saham.

Wibawa (2015) mendukung penelitian Rozeff (1982) yang menyatakan terdapat pengaruh positif antara leverage dengan saham bonus. Leverage digunakan sebagai alat ukur jumlah aktiva yang dibiayai oleh pinajaman dari luar. Jumlah pinjaman yang dimanfaatkan untuk mendanai aktiva tidak berasal dari pemegang saham maupun investor, melainkan berasal dari kreditor (Sudarmadji, 2007). Keuntungan dan kerugian yang merupakan risiko penggunaan hutang dapat dihasilkan oleh penggunaan hutang dalam memenuhi kebutuhan dana pada perusahaan. Pinjaman dari luar mengakibatkan beban tetap berupa bunga, sedangkan disisi lain pinjaman dari luar adalah dana yang dapat digunakan untuk membiayai aktivitas operasi perusahaan sehingga menghasilkan suatu peningkatan pada keuntungan yang dihasilkan perusahaan. Sisi positif dari adanya beban bungaadalah menjadi faktor yang dapat mengurangi pajak penghasilan (Miller dan Scholes, 1978).

Penelitian Herry dan Hamin (2005) menunjukkan bahwa nilai perusahaan meningkat disebabkan oleh leverage, sumber dana operasi yang digunakan perusahaan juga dinyatakan oleh leverage. Risiko yang dihadapi perusahaan juga ditunjukkan oleh rasio leverage. Peningkatan risiko perusahaan mengakibatkan peningkatan ketidakpastian perusahaan dalam menghasilkan keuntungan dimasa yang akan datang. Foster (2006:214) menyatakan bahwa terdapat hubungan antara leverage dengan return perusahaan. Howton et al. (1998) menyatakan perusahaan yang memiliki leverage tinggi tidak memiliki peluang investasi yang menguntungkan serta tingginya arus kas bebas dengan membedakan proporsi pembagian deviden perusahaan dari tingkat yang rendah ke tinggi. Crabb (2003:161) mengungkapkan bahwa harga saham perusahaan dipengaruhi oleh rendahnya pembayaran deviden pada saat pengumuman penawaran hutang.

Kemampuan perusahaan dalam memanfaatkan aktiva yang memiliki beban tetap untuk meningkatkan return dinyatakan oleh leverage. Sutrisno (2006:132) mendefinisikan leverage sebagai pemanfaatan aktiva yang bersifat tetap dimana perusahaan harus menanggung beban tetap berupa bunga setiap periode yang telah ditetapkan. Tingkat leverage yang semakin meningkat menyebabkan peningkatan tingkat uncertainty, namun disisi lain peningkatan tersebut menyebabkan peningkatan pada return yang akan didapatkan perusahaan. Setiap perusahaan memiliki nilai leverage yang berbeda, perbedaan tersebut terletak pada periodenya, namun yang pasti leverage yang meningkat akan diikuti oleh peningkatan risiko dan return yang diinginkan perusahaan.

Rasio leverage menyatakan kebijakan hutang, dari hutang tersebut dapat diperkirakan laba yang akan diperoleh investor dari hasil investasinya. Hutang tersebut diduga mempengaruhi pengambilan kebijakan saham bonus oleh perusahaan sebab ketika perusahaan mendapatkan return dan penurunan dalam pembagian deviden kepada pemegang saham, dengan demikian perusahaan dipandang perlu untuk mengambil kebijakan saham bonus.

Rentabilitas modal sendiri atau rentabilitas usaha ditunjukkan oleh nilai return on equity (ROE) suatu perusahaan. Rentabilitas modal sendiri (ROE) menurut Riyanto (2010:116) merupakan perbandingan antara total keuntungan bagi pemilik modal sendiri di satu pihak dengan total ekuitas yang menghasilkan keuntungan di pihak yang lain. Penelitian Wibawa (2015) menunjukkan hasil bahwa rentabilitas berpengaruh negatif terhadap saham bonus serta didukung oleh penelitian Suharli (2006), Lestari dan Sugiharto (2007) yang menyatakan bahwa peningkatan nilai ROE suatu perusahaan menggambarkan terjadi peningkatan kinerja perusahaan dalam pengelolaan modal sehingga pemengang saham akan memperoleh peningkatan jumlah deviden yang akan diterima. Tingginya angka ROE suatu perusahaan menggambarkan bahwa jumlah modal yang dimanfaatkan untuk aktivitas perusahaan mampu menghasilkan keuntungan bagi perusahaan, dengan demikian peluang perusahaan mengambil kebijakan saham bonus rendah.

$\mathrm{H}_{1}$ : Return on equity (ROE) berpengaruh negatif pada saham bonus.

Leverage merupakan perbandingan yang menunjukkan hubungan antara hutang perusahaan terhadap modal maupun aktiva. Menurut Raharjaputra (2009:88) besar kecilnya perusahaan membiayai aktivitas operasinya melalui 
perbandingan antara modal sendiri yang telah disetorkan dengan jumlah hutang dari kreditor diukur dengan menggunakan leverage. Penelitian Budi (2009) menunjukkan hasil bahwa terdapat pengaruh antara leverage terhadap kebijakan deviden. Rozeff (1982) menyatakan bahwa perusahaan yang memiliki nilai DFL (degree of financial leverage) dan DOL (degree of operatingleverage) tinggi akan mengalami penurunan dalam pembagian deviden kepada pemegang saham sebab perusahaan akan mengurangi pembagian deviden dengan tujuan untuk menurunkan tingkat ketergantungan atas pinjaman dana dari luar. Wibawa (2015) mendukung penelitian Rozeff (1982) yang menyatakan bahwa terdapat pengaruh positif antara leverage terhadap pengambilan kebijakan saham bonus oleh perusahaan. bonus.

$\mathrm{H}_{2}$ : Leverage berpengaruh positif pada saham

\section{METODE PENELITIAN}

Penelitian ini menggunakan pendekatan kuantitatif yang berbentuk asosiatif yang bertujuan untuk mengetahui hubungan antara dua variabel atau lebih, maka secara skematis penelitian ini dapat disajikan sebagai berikut.

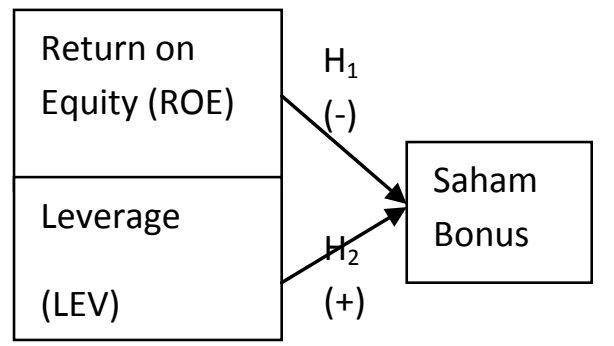

Gambar 1. Desain Penelitian

Keterangan :

Saham bonus

ROE

$=$ variabel independen

LEV

= variabel dependen

$=$ variabel dependen

Penelitian ini dilakukan pada perusahaan yang terdaftar di Bursa Efek Indonesia (BEI) tahun 2000-2015 dengan mengunduh laporan keuangan tahunan perusahaan yang diakses melalui situs www.idx.co.id. Obyek dari penelitian ini adalah return on equity (ROE), leverage dan saham bonus pada perusahaan yang terdaftar di Bursa Efek Indonesia (BEI) tahun 2000-2015.

Variabel bebas dalam penelitian ini adalah return on equity (ROE) dan leverage. ROE merupakan presentase yang membandingkan EAT (earnings after tax) dengan jumlah ekuitas (Lestari, dkk. 2007). Return on equity (ROE) dapat dihitung dengan menggunakan rumus:

ROE $=\frac{\text { Laba Bersih Setelah Pajak }}{\text { Total Modal }} \times 100 \%$ (1)

Leverage pada penelitian ini diproksi dengan DER. Pemilihan Debt to Equity Ratio (DER) sebagai proksi leverage didasarkan atas rasio ini digunakan oleh investor untuk menilai kondisi perusahaan melalui perbandingan hutang yang dimiliki dengan modal yang dimiliki perusahaan. Debt to Equity Ratio (DER) adalah presentase yang membandingkan jumlah pinjaman yang dimiliki perusahaan dari luar dengan jumlah modal yang dimiliki (Ang, 2007:96). Debt to Equity Ratio (DER) dapat dihitung dengan menggunakan rumus:

$$
\text { DER }=\frac{\text { Total Hutang }}{\text { Total Modal }} \times 100 \%
$$

Variabel terikat dalam penelitian ini adalah saham bonus. Saham bonus merupakan presentase yang membandingkan jumlah saham bonus dengan jumlah saham yang beredar (Samsul, 2006:122). Saham bonus dapat dihitung dengan menggunakan rumus:

Saham

Bonus $=\frac{\text { Jumlah Saham yang Beredar }}{\text { Jumlah Saham Bonus }} \times 100 \%$

Data kuantitatif yang digunakan dalam penelitian ini adalah laporan posisi keuangan, laporan laba rugi, dan laporan perubahan ekuitas perusahaan yang membagikan saham bonus yang terdaftar di Bursa Efek Indonesia (BEI) tahun 20002015. Data kualitatif dalam penelitian ini meliputi daftar dan profil perusahaan yang terdaftar di Bursa Efek Indonesia (BEI) tahun 2000-2015. Data sekunder dalam penelitian ini adalah data yang terdapat dalam laporan keuangan tahunan terkait return on equity (ROE), leverage dan saham bonus pada perusahaan yang terdaftar di Bursa Efek Indonesia (BEI) tahun 2000-2015 yang diunduh dari situs www.idx.co.id.

Populasi dalam penelitian ini adalah seluruh perusahaan yang terdaftar di Bursa Efek Indonesia (BEI) tahun 2000-2015. Penelitian ini menggunakan teknik sampling jenuh dimana sampel dalam penelitian ini adalah perusahaan-perusahaan yang melakukan pengumuman saham bonus periode 2000-2015 di Bursa Efek Indonesia (BEI).

Berdasarkan data laporan keuangan tahunan perusahaan yang diunduh pada situs www.idx.co.id, maka diperoleh sampel yang akan 
digunakan dalam penelitian ini berjumlah 36 data amatan. Akan tetapi pada saat pengolahan data telah terjadi outlier data sebanyak 3 data amatan, sehingga jumlah sampel yang digunakan berjumlah 33 data amatan.

Penelitian ini menggunakan data sekunder. Data sekunder yang digunakan dalam penelitian ini diperoleh melalui metode observasi non partisipan, sehingga peneliti hanya sebagai pengamat independen. Data sekunder tesebut dianalisis menggunakan teknik analisis regresi linear berganda. Model regresi yang digunakan dalam penelitian ini adalah sebagai berikut.

$$
Y=\alpha+\beta 1 X 1+\beta 2 X 2+e
$$

Keterangan:

$$
\begin{array}{ll}
\mathrm{Y} & =\text { Saham bonus } \\
\mathrm{a} & =\text { Konstanta } \\
\beta 1, \beta 2 & =\text { Koefisien regresi } \\
\mathrm{X} 1 & =\text { Return on Equity (ROE) } \\
\mathrm{X} 2 & =\text { Leverage } \\
\mathrm{e} & =\text { Error }
\end{array}
$$

\section{HASIL DAN PEMBAHASAN}

Statistik deskriptif digunakan dalam menggambarkan nilai rata-rata (mean), nilai minimum, nilai maksimum dan standar deviasi dari variabel yang diteliti. Pada Tabel 2 akan disajikan hasil analisis statistik deskriptif dari masing-masing variabel yang akan diteliti. Hasil analisis uji statistik pada Tabel 2 menunjukan bahwa variabel return on equity (ROE) memiliki nilai mean sebesar 9,6745, yang memiliki arti bahwa rata-rata besarnya modal yang mampu dihasilkan oleh perusahaan sampel adalah sebesar 9,67 persen. Nilai standar deviasi return on equity (ROE) adalah sebesar 9,85326 yang menjelaskan variasi dalam variabel return on equity (ROE). Nilai minimum sebesar -21,13 persen menunjukkan kemmpuan perusahaan dalam menghasilkan laba dari jumlah modal yang terendah dari keseluruhan jumlah saham yang dimiliki perusahaan, sementara nilai maksimumnya adalah sebesar 26,87 persen yang diperoleh PT. Mayora Indah pada tahun 2013. Nilai minimum diperoleh PT. Jaya Pari Steel di tahun 2010.

Tabel 2.

Hasil Uji Statistik Deskriptif Variabel

\begin{tabular}{lrlrrr}
\hline & N & Min & Max & Mean & \multicolumn{1}{c}{$\begin{array}{l}\text { Std. } \\
\text { Dev }\end{array}$} \\
\hline ROE & 33 & $(21,13)$ & 26,87 & 9,6745 & 9,85326 \\
Leverage & 33 & 10,45 & 91,42 & 47,1076 & 22,53767 \\
Saham & 33 & 0,70 & 50,00 & 23,6636 & 16,31846 \\
Bonus & & & & &
\end{tabular}

Valid N 33

(listwise)

\section{Sumber: Data sekunder diolah, 2016}

Leverage memperoleh mean sebesar 47,1076 yang memiliki arti bahwa aktiva yang dibiayai dari hutang perusahaan adalah sebesar 47,11 persen. Nilai standar deviasi leverage adalah sebesar 22,53767 yang menjelaskan besarnya variasi yang terdapat dalam variabel leverage. Nilai minimum sebesar 10,45 persen dan nilai maksimum sebesar 91,42 persen. Nilai minimum ataupun maksimum ini memiliki makna bahwa kemampuan perusahaan dalam membayar aktiva perusahaan dengan utang perusahaan. Nilai minimum ditempati oleh PT. Intanwijaya Internasional di tahun 2004. Nilai maksimum diraih oleh PT. Bank Mega di tahun 2009.

Saham bonus memiliki nilai rata-rata sebesar 23,6636 yang menunjukkan bahwa perusahaan sampel membagikan 23,66 persen saham bonus dari keseluruhan saham yang dimiliki perusahaan. Nilai standar deviasi sebesar 16,31846 berarti nilai variasi yang dimiliki saham bonus sebesar 16, 31 persen. Nilai minimum menjelaskan bahwa perusahaan sampel membagikan saham bonus paling rendah sebesar 0,7 persen dari keseluruhan saham yang dimiliki oleh perusahaan. Nilai minimum ini diraih oleh PT. Intanwijaya Internasional tahun 2001. Nilai maksimum adalah kemampuan perusahaan sampel membagikan

\begin{tabular}{|c|c|c|c|c|c|}
\hline \multirow[t]{2}{*}{ Model } & \multicolumn{2}{|c|}{$\begin{array}{l}\text { Unstandardized } \\
\text { Coefficients }\end{array}$} & \multirow{2}{*}{$\begin{array}{c}\text { Standar } \\
\text { dized } \\
\text { Coeffici } \\
\text { ents } \\
\text { Beta }\end{array}$} & \multirow[t]{2}{*}{$\mathrm{T}$} & \multirow[t]{2}{*}{ Sig. } \\
\hline & B & $\begin{array}{l}\text { Std. } \\
\text { Error }\end{array}$ & & & \\
\hline (Constant) & 0,138 & 0,065 & & 2,109 & 0,043 \\
\hline ROE & $-0,367$ & 0,275 & $-0,221$ & $-1,331$ & 0,193 \\
\hline Leverage & 0,286 & 0,120 & 0,394 & 2,371 & 0,024 \\
\hline Adjusted $\mathrm{R}^{2}$ & & & & & 0,129 \\
\hline Fhitung & & & & & 3,361 \\
\hline Sig. Fhitung & & & & & 0,048 \\
\hline
\end{tabular}
saham bonus dengan jumlah tertinggi yaitu sebesar 50 persen dari total saham yang dimiliki perusahaan sampel. Nilai maksimum ini diraih oleh PT. Summarecon Agung di tahun 2008.

Tabel 3.

Hasil Analisis Uji Regresi Linear Berganda

Sumber: Hasil olahan SPSS, 2016

Sebelum dilakukan analisis, model ini telah melalui pengujian untuk memastikan bahwa model terbebas dari permasalahan terkait asumsi klasik. Berdasarkan hasil analisis pada Tabel 3 menunjukkan bahwa nilai signifikansi $\mathrm{F}$ sebesar 
0,048 lebih kecil dari 0,05, sehingga dapat disimpulkan bahwa seluruh variabel bebas yang digunakan dalam penelitian ini berpengaruh terhadap saham bonus. Hal ini menunjukkan bahwa model penelitian yang dibuat layak untuk diteliti dan pengujian hipotesis dapat dilanjutkan. Hasil analisis uji koefisien determinasi $\left(\mathrm{R}^{2}\right)$ yang dpat dilihat di Tabel 3 menunjukkan nilai $\mathrm{R}^{2}$ sebesar 0,129. Ini menunjukkan bahwa varian dari variabel bebas ROE dan leverage mampu menjelaskan variabel terikat saham bonus sebesar 12,9 persen, sedangkan sisanya 87,1 persen dijelaskan oleh variabel lain yang tidak dimasukan dalam model penelitian ini.

asil analisis pada uji regresi Tabel 3, menunjukkan persaman regresi yang dibuat adalah sebagai berikut.

$$
\mathrm{Y}=0,138-0,367 \mathrm{X}_{1}+0,286 \mathrm{X}_{2}+\varepsilon
$$

Nilai konstanta sebesar 0,138 memiliki arti apabila return on equity (ROE) dan leverage perusahaan konstan, maka pembagian saham bonus perusahaan adalah sebesar 13,8 persen. Nilai koefisien return on equity (ROE) adalah -0,367 yag bererti bahwa apabila return on equity (ROE) perusahaan meningkat 1 persen maka pembagian saham bonus akan menurun 36,7 persen. Nilai koefisien leverage yaitu 0,286 berarti bahwa ketika leverage meningkat 1 persen maka pembagian akan meningkat pula yaitu menjadi 28,6 persen.

Hasil anlisis pada Tabel 3 menunjukkan bahwa nilai $t$ sebesar -1,331 dengan nilai signifikansi sebesar 0,193 lebih besar dari taraf nyata 0,05 memiliki makna bahwa variabel return on equity (ROE) tidak berpengaruh terhadap saham bonus. Oleh karena itu hipotesis yang menyatakan bahwa return on equity (ROE) berpengaruh negatif pada saham bonud atau $\mathrm{H}_{1}$ ditolak.

Hasil ini mengindikasikan bahwa semakin tinggi tingat return on equity (ROE) di suatu perusahaan maka para pemegang saham atau investor akan mendapatkan kesejahteraan tetapi bukan dalam bentuk saham bonus, melainkan dalam bentuk deviden tunai. Hasil penelitian ini sesuai dengan hasil penelitian terdahulu yang dilakukan oleh Suharli (2006), Lestari dan Sugiharto (2007), yang menyatakan bahwa semakin tinggi return on equity (ROE) yang dimiliki oleh suatu perusahaan maka akan semakin baik kinerja perusahaan dalam melakukan tata kelola modalnya dan para pemegang saham atau investor akan memperoleh deviden yang semakin meningkat. Hasil penelitian ini tidak sejalan dengan penelitian terdahulu yang dilakukan oleh Wibawa (2015), yang menyatakan bahwa rentabilitas berpengaruh negatif pada saham bonus. Pengaruh tersebut menjelaskan bahwa laba yang diperoleh perusahaan baik itu laba besar maupun laba yang kecil akan mepengaruhi besar kecilnya pembagian deviden. Apabila suatu perusahaan mengumumkan peningkatan deviden, maka pemegang saham akan menganggap kondisi perusahaan relative stabil dan begitu juga sebaliknya apabila perusahaan mengumumkan akan terjadi penurunan pembagian deviden maka pemegang saham akan menganggap perusahaan sedang mengalami kondisi yang tidak stabil.

Nilai return on equity (ROE) di suatu perusahaan akan menunjukan seberapa baik tata kelola manajemen dalam memanfaatkan investasi para pemegang saham. Nilai return on equity (ROE) yang tinggi mengindikasikan bahwa tingkat pengembalian deviden yang akan diterima investor lebih tinggi sehingga investor akan lebih tertarik untuk membeli saham tersebut, dan ini yang menyebabkan harga pasar saham akan cenderung meningkat. Harga pasar yang mengalami peningktan ini akan meningkatkan volume perdagangan saham serta likiditas perusahaan di masa mendatang. Para investor pada umumnya selalu menginginkan pembagian deviden yang relatif stabil, sehingga mengurangi ketidakpastian investor dalam menanamkan modal kedalam perusahaan. Di sisi lain, perusahaan yang akan membagikan deviden dihadapkan pada berbagai pertimbangan seperti perlunya menahan sebagian laba untuk re-investasi yang memungkinkan lebih menguntungkan, kebutuhan dana di dalam perusahaan, likuiditas perusahaan, sifat pemegang saham, pencapaian target tertentu yang berhubungan dengan rasio pembayaran deviden serta faktor lainnya yang berhubungan dengan kebijakan deviden.

Semakin besar nilai return on equity menjukan bahwa tingkat pengembalian yang diharapkan oleh investor juga semakin meningkat. Semakin besar nilai return on equity maka akan menjadikan perusahaan tersebut dianggap semakin menguntungkan dan para investor akan tertarik menanamkan saham sehingga akan menyebabkan permintaan bertambah dan harga penawaran di pasar sekunder cenderung terus mengalami peningktan. Meningkatnya laba akan mempengaruhi besarnya deviden yang dibagikan dari total keuntungan bersih yang diperoleh perusahaan kepada investor (Mehta, 2012). Besarnya keuntungan yang diperoleh akan berpengaruh terhadap besarnya deviden yang dapat dibagikan oleh perusahaan. 
Pembayaran deviden dalam bentuk tunai (cash deviden) lebih banyak diinginkan oleh investor dari pada dalam bentuk lain seperti saham bonus, karena pembayaran deviden tunai membantu mengurangi ketidakpastian dalam pelaksanaan aktivitas investasinya pada suatu perusahaan yang dibandingkan dengan pemberian saham bonus karena tidak akan menmbah volume investasi dari para pemegang saham sehingga dapat dikatakan bahwa besar kecilnya nilai retun on equity suatu perusahaan tidak berpengaruh pada kebijakan saham bonus yang akan dilakukan oleh perusahaan.

Pengaruh leverage pada saham bonus menunjukkan nilai $t$ sebesar 2,371 dengan nilai signifikansi t sebesar 0,024 yang berarti lebih kecil dari taraf nyata 0,05 maka dapat disimpulkan bahwa variabel leverage berpengaruh positif dan signifikan pada saham bonus, sehingga dapat disimpulkan bahwa hipotesis yang menyatakan leverage berpengaruh positif pada saham bonus $\left(\mathrm{H}_{2}\right)$ diterima. Variabel leverage berpengaruh positif dan signifikan pada saham bonus. Maka dari itu, hasil penelitian ini menerima $\mathrm{H}_{2}$ yang menyatakan bahwa leverage berpengaruh positif pada saham bonus. Hasil penelitian ini mengindikasikan peningkatan nilai leverage akan menyebabkan investor mendapatkan kesejahteraan dalam saham bonus, bukan dalam bentuk deviden tunai.

Bukti empiris menunjukkan hasil penelitian ini mendukung penelitian Rozzeff (1982) dan Wibawa (2015) menunjukkan bahwa leverage berpengaruh positif terhadap saham bonus serta Budi (2009) yang menyatakan terdapat pengaruh antara leverage terhadap kebijakan deviden. Rasio leverage menyatakan bahwa kebijakan utang dapat digunakan untuk memperkirakan laba yang kemungkinan dapat diperoleh bagi investor jika melakukan investasi pada suatu perusahaan. Hutang tersebut dapat mempengaruhi pengambilan kebijakan saham bonus karena jika perusahaan memperoleh return, perusahaan cenderung memenuhi kewajibannya terlebih dahulu sehingga kemungkinan pembayaran deviden pada investor rendah, sehingga kebijakan saham dalam perusahaan tersebut dapat terlaksana.

Leverage digunakan dalam penggambaran kemampuan perusahaan untuk menggunakan aktiva dan dana yang mempunyai beban tetap (fixed cost assets or funds) untuk meningkatkan tingkat penghasilan (return) untuk pemegang saham. Sutrisno (2006:132) menyatakan bahwa leverage tidak lain adalah penggunaan aktiva tetap atau sumber dana dimana atas penggunaan dana, perusahaan harus menanggung biaya tetap atau membayar beban tetap. Semakin besar tingkat leverage menunjukkan terjadinya tingkat ketidakpastian (uncertainty) dari penghasilan yang akan diperoleh akan semakin tinggi pula, tetapi pada saat yang sama hal tersebut juga akan memperbesar jumlah penghasilan yang akan diperoleh. Tingkat leverage berbeda-beda antara suatu perusahaan dengan perusahaan lainnya dan terdapat perbedaan dari satu periode ke periode lainnya di dalam suatu perusahaan. Semakin tinggi tingkat leverage yang dimiliki oleh perusahaan maka semakin tinggi resiko yang dihadapi serta semakin besar tingkat penghasilan (return) yang diharapkan. Hasil studi emperis Junaid dan Shah (1999) menyatakan resiko (risk) dalam leverage dimaksudkan dengan ketidakpastian (uncertainty) dalam hubungannya dengan kemampuan perusahaan membayar kewajiban-kewajiban tetapnya (fixed payment obligation).

Perusahaan yang menerapkan leverage memiliki tingkat kekayaan perusahaan yang meningkat. Permasalahan leverage akan selalu dihadapi oleh perusahaan karena leverage selalu berurusan dengan biaya tetap operasi maupun biaya finansial. Biaya tetap operasi ialah biaya yang harus dikeluarkan oleh perusahaan dalam mengadakan kegiatan investasi baik itu investasi perlengkapan, peralatan, ataupun juga investasi jangka panjang. Biaya finansial merupakan biaya yang wajib dihitung oleh perusahaan akibat dari fungsi perusahaan dalam menjalankan pendanaan untuk kelangsungan perusahaan itu sendiri. Beban ataupun biaya tetap yang telah perusahaan hitung merupakan dampak yang harus menjadi tanggung jawab perusahaan karena telah melakukan fungsi finansial dan juga keputusan dalam mengatur laju keuangan perusahaan.

Pembagian saham bonus dipandang dapat menjadi alternatif bagi perusahaan yang memiliki tingkat leverage tinggi karena dengan dibagikannya saham baru secara cuma-cuma kepada pemegang saham menyebabkan perusahaan tidak lagi mengeluarkan deviden tunai kepada pemegang saham, sehingga perusahaan dapat memenuhi kewajibannya terlebih dahulu yang kedepannya juga akan berpengaruh pada likuiditas perusahaan dan volume perdagangan saham yang meningkat.

\section{SIMPULAN}

Berdasarkan hasil penelitian diatas maka dapat disimpulkan bahwa return on equity (ROE) tidak berpengaruh pada saham bonus. Hasil penelitian 
ini memberikan indikasi bahwa peningkatan nilai return on equity (ROE) suatu perusahaan menyebabkan para pemegang saham atau investor akan mendapatkan keuntungan dalam bentuk deviden tunai, bukan dalam bentuk saham bonus. Leverage berpengaruh positif dan signifikan pada saham bonus. Hasil penelitian ini memberikan indikasi bahwa peningkatan nilai leverage suatu perusahaan menyebabkan pemegang saham akan mendapatkan keuntungan dalam bentuk saham bonus, bukan dalam bentuk deviden tunai.

Hasil penelitian ini menunjukkan bahwa return on equity (ROE) dan leverage mampu memprediksi saham bonus hanya sebesar $12,9 \%$. Sisanya sebesar $87,1 \%$ tidak dijelaskan dalam model atau dijelaskan oleh sebab-sebab lain diluar model regresi. Keterbatasan lain dari penelitian ini adalah periode pengamatan yang hanya dilakukan pada tahun 2000-2015 sehingga jumlah data/sampel yang diperoleh dari pengumuman perusahaan yang membagikan saham bonus sedikit. Melalui keterbatasan tersebut maka saran yang dapat diberikan yaitu diharapkan bagi peneliti berikutnya bisa menambah variabel lain yang mungkin dapat lebih meningkatkan prediksi dan mempengaruhi dilakukannya kebijakan saham bonus oleh perusahaan serta memperluas periode pengamatan sehingga jumlah data amatan atau sampel yang dihasilkan lebih banyak.

\section{REFERENSI}

Adaoglu, Cahit dan M. Ameziane Lasfer. 2003. The Market Valuation of Bonus Issues in a Closely Held Market. Journal of Business Finance and Accounting, 38 (5-6), hal: 601-627.

Adiati, Arum Kusumaningdyah. 2006. Pengaruh Pengumuman Saham Bonus Terhadap Pergerakan Harga Saham. Jurnal Bisnis \& Manajemen, 6 (2), hal: 175-184.

Anthony, R dan Vijay Govindarajan. 2006. Management Control System. Jilid I. Jakarta: Salemba Empat.

Balachandran., Balasingham dan Sally Tanner. 2001. Bonus Shares Issues and Announcement Effect: Australian Evidence. Monash Economic Journal, 21 (1), hal: 1-25.

BAPEPAM-LK. 2003. Pasar Modal Indonesia. Jakarta.

Barclay, M.J. dan C.G. Holderness. 1990. Private Benefits from Control of Public Corporations,
Journal of Financial Economics, 25 (2), hal: 371395.

Barnes, Michelle L. dan Shiguang Ma. 2002. The Behaviour of China's Stock Price in Response to the Proposal and Approval of Bonus Issues. Journal of Financial Economics, 20 (2), hal: 279285.

Budi, Sanjaya. 2009. Analisis Faktor-Faktor yang Mempengaruhi Kebijakan Dividen pada Perusahaan Publik di Indonesia. Jurnal Kajian Akuntansi, 4 (1), hal: 15-24.

Crabb, Peter R. 2003. Finance and Investment using The Wall Street Journal. New York: McGrawHill.

Crutchley, Claire., E. Marlin., R.H. Jensen., John S. Jahera., Jr. Jennie., E. Raymond. 1999. Agency Problem and The Simultaneity of Financial Decision Making The Role of Institutional Ownership. International Review of Financial Analysis, 8 (2), hal: 177-197.

Foster, George. 2006. Financial Statement Analysis. Englewood Cliffs, New Jersey: Prentice-Hall, A Division of Simon \& Schuster, Inc.

Gitman, Lawrence J. 2006. Principles of Manajerial Finance. USA: Pearson Addision Wesley.

Hebble, Annette. 2005. Corporate Governance and Firm Characteristic. Journal of Business \& Economics Research, 3 (5), hal: 27-31.

Herry, Wiranto dan Hamin. 2005. Tingkat Kepemilikan Manajerial dan Nilai Perusahaan: Bukti Empiris pada Perusahaan Publik di Indonesia. Jurnal Simposium Riset Ekonomi, 23 (2), hal: 1-16.

Holderness, C.G. dan Sheehan, D.P. 1988, The Role of Majority Shareholders in Publicly Held Corporations: an Exploratory Analysis, Journal of Financial Economics, 20 (2), hal: 317-346.

Howton, S.D., S.W. Howton dan S.B. Perfect. 1998. The Market Reaction to Straight Debt Issues: The Effects of Free Cash Flow. The Journal of Financial Research, 21 (2), hal: 219-228.

Jensen, M. C. dan W.H. Meckling. 1976. Theory of The Firm: Managerial Behavior, Agency Cost 
and Ownership Structure. Journal of Financial Economics, 22 (3), hal: 305-360.

Jones, P. Charles. 2006. Investments: Analysis and Management. Journal of Financial Economics, 2 (4), hal: 405-460.

Junaid, Muhammad Iqbal dan Syed Zulfiqar Ali Shah. 2011. Determinants of Systematic Risk. The Journal of Commerce, 4 (1), hal: 47-56.

Kennedy, Posma Sariguna Johnson. 2003. Analisis Pengaruh dari Return on Asset, Return on Equity, Earnings Per Share, Profit Margin, Asset Turnover, Rasio Leverage dan Debt to Equity Ratio terhadap Return Saham (Studi terhadap Saham-saham yang Termasuk dalam LQ-45 di BEJ Tahun 2001). Tesis. Program Pascasarjana Universitas Indonesia, Jakarta.

Lestari, Annio Indah., Muslich Lutfi dan Syahyunan. 2007. Pengaruh Faktor Fundamental dan Teknikal Terhadap Harga Saham Properti yang Terdaftar di Bursa Efek Jakarta. Jurnal Ekonomi, Bisnis dan Akuntansi, 2 (2), hal: 87-109.

Lestari, Maharani Ika dan Toto Sugiharto. 2007. Kinerja Bank Devisa dan Bank Non Devisa dan Faktor-Faktor yang Mempengaruhinya. Proceeding PESAT (Psikologi, Ekonomi, Sastra, Arsitek \& Sipil), 2 (2), hal: 220-229.

Mehta, Anupam. 2012. An Empirical Analysis of Determinants of Dividend Policy-Evidence from the UAE Company. Global Review of Accounting and Finance, 3 (1), hal: 120-150.

Miller, M., dan M. Scholes. 1978. Dividend and Taxes. Journal of Financial Economics, 23 (1), hal: 333-364.

Raharjaputra, Hendra S. 2009. Manajemen Keuangan dan Akuntansi. Jakarta: Salemba Empat.

Riyanto, Bambang. 2010. Dasar-Dasar Pembelanjaan Perusahaan. Edisi IV. Yogyakarta: BPFE.

Rozeff, M. 1982. Beta and Agency Cost as Determinants of Payout Ratio. Journal of Financial Research. 2 (2), hal: 249-259.

Samsul, Mohamad. 2006. Pasar Modal dan Manajemen Portofolio. Jakarta: Erlangga.
Shirur, Srinivas. 2008. Dilemma of Corporate Action: Empirical Evidences of Bonus Issue vs Stock Split. Vikalpa. 33 (1), Hal: 35-47.

Sianipar, Ardin. 2006. Pengaruh Faktor Fundamental Terhadap Harga Saham Industri Perbankan di Indonesia. Tesis. Magister Akuntansi Pascasarjana Universitas Sumatera Utara.

Sjahrial, Dermawan. 2007. Manajemen Keuangan. Jakarta: Wacana Media.

Sudarmadji, Sularto. 2007. Pengaruh Ukuran Perusahaan, Profitabilitas, dan Tipe Kepemilikan Perusahaan terhadap Luas Voluntary Disclousure Laporan Keuangan Tahunan. Jurnal Akuntansi dan Bisnis, 2 (2), hal: 149-155.

Suharli, Michell, 2006. Studi Empiris Mengenai Pengaruh Profitabilitas, Leverage dan Harga Saham Terhadap Jumlah Dividen Tunai (Studi pada Perusahaan yang Terdaftar di Bursa Efek Jakarta Periode 2002-2003). Jurnal MAKSI, 6 (2), hal: 243-256.

Sunariyah, Siti. 2010. Teori Pasar Modal. Yogyakarta: BPFE.

Sutrisno. 2006. Manajemen Keuangan: Teori, Konsep dan Aplikasi. Yogyakarta: EKONISIA.

Wibawa, Oka Surya IB. 2015. Pengaruh Rentabilitas dan Leverage pada Saham Bonus di Perusahaan yang Terdaftar di BEI periode 2000-2014. Jurnal Ekonomi, Bisnis dan Akuntansi, 16 (2), hal: 1433-1460. 